\title{
The New Leviathan: the Chicago School and the Chilean Regime 1973-80
}

\section{Philip O'Brien}

Our inquiry is not after that which is perfect, well knowing that no such thing is found among men; but we seek that human Constitution which is attended with the least, or the most, pardonable inconvenience.

(Algernon Sidney, quoted on the title page of F. A. Hayek's The Constitution of Liberty)

Si a la Constitucion de la Libertad (main government slogan during the campaign for the new Chilean Constitution, September 1980)

\section{Introduction}

Chile is of fairly limited strategic importance both in terms of its geopolitical position and its natural resources. Nevertheless, it has aroused world-wide interest for the various political-economic-social experiments it has undergone in the last 15 years: from the Christian Democratics' 'Revolution in Liberty' to the essentially Euro-Communist 'Democratic Transition to Socialism' and to the Chicago social market economy within 'The Constitution of Liberty'. Each experiment was seen by its proponents as the long-run solution to Chilean political and economic problems, and each experiment involved learned debates on its supposed 'irreversibility'.

The present Chilean model, ideologically inspired by the so-called Chicago School, and to a great extent financed by private banks, arouses as deep a controversy as the previous two models. This controversy has received a wider airing with the electoral victory of Margaret Thatcher in Britain and Ronald Reagan in the USA. For all three governments invoke a rhetoric which, allowing for national differences, reveal a common economic foundation: the antistatism, pro free market 'monetarist' prescriptions associated with the Chicago School of Milton Friedman and Friedrich von Hayek'.

${ }^{1}$ The then British Minister of Trade Cecil Parkinson, acknowledged the validity of the comparison between Britain and Chile, when he pointed out that Britain is trying, as Chile has done, to reduce tariffs. public expenditure, state bureaucracy and taxes on profits; to reduce controls and restrictions on prices, salaries, exchange rates and investment; to break state monopolies; and, in brief, to re-establish the role of the private sector and reduce that of the public. "The Chilean economic experience', he concluded, 'is very similar to what we are developing here', though 'in the case of Chile it was possible to impose a policy and regulate its implementation. but this isn't possible in our country. Here we have to proceed with more caution and convince people of the benefits of our policies' $\{$ El Mercurio, Edicion Internacional, 5 November 1980 l.

It could be argued that Reagan's economic programme with its emphasis on the 'supply side' the Laffer curve et al has nothing to do
It is this seemingly paradoxical combination of economic market individualism and freedom with a political authoritarian inclined state which characterises the dominant trend of the new right-wing forces in Western capitalism. The particular mix of that combination depends on national circumstances with the political authoritarianism of the 'new democracy' in Chile, for example, reaching extremes. The emergence of this bloc in developed capitalist societies marks the defeat (perhaps temporary) of Keynesian social consensus politics and economics.

The article is concerned with analysing the Chicago strategy and how it became the dominant strategy in Chile after the coup of 11 September 1973. The first part looks at the relationship between the Chicagotrained economists and the making of the coup. The second analyses some of the key policy decisions within the main stages of the Chilean process. The third part attempts to analyse the model as a totality, with a look at some of its main contradictions.

\section{The Chicago School and the Chicago Boys}

One of the peculiarities of Chile is that thanks to an agreement signed between the University of Chicago and the Catholic University of Chile in 1955, a large number of Chilean economists, 'the brightest and the best', had studied postgraduate economics at the University of Chicago. Between 1955 and 1963 this exchange was financed by the USA Government Aid Agency (the USA Institute of International Assistance originally justified financing this link on the ground that it was important to combat the spread of ECLA ideas), and thereafter Chilean businessmen and others financed the scheme. Not every Chilean of course who studied in Chicago became an adherent of the extremist Chicago philosophy, but it is amazing how many of the Chilean Chicago Boys did (the name commonly given in Chile to the Chicago trained economists). They became determined not only to gain control of the Economics Department of the Catholic University, but to find a wider audience for their views. In the words of one of them, "we set out to win elite opinion to our positions; and to do this we concentrated on the quality media' (interview with $\mathrm{E}$. Sanfuentes, May 28 1980). Even before Allende's victory, Chicago Boys obtained important footholds in the media, writing, for example in the Economic

with Chicago orthodoxy. Much of the 'supply side' economics, however, is pure public relations (outside of defence, which is compatible with Chicago) and the programme is essentially that of Chicago. 
Page of El Mercurio. And with the establishment of the influential weekly Que Pasa (owned by a Chicago Boy) the Chicago philosophy spread rapidly. In 1968 a group of Chicago Boys established a right-wing think tank, CESEC ${ }^{2}$ and through it attempted to push the programme of the right-wing Presidential candidate, Jorge Alessandri, in the direction of the Chicago model. CESEC was asked to draw up Alessandri's economic programme; but the Chicago model was opposed by many of Alessandri's business supporters and had to be put into cold storage 'as it was a programme difficult to implement within a democracy', as one leading businessman, M. Valdes, ex-President of the Confederation of Production and Commerce, put it (interview 17 June 1980). Nevertheless the campaign was useful in winning important adherents to the Chicago plan among key businessmen.

The philosophy behind the Chicago plan is a very simple one; a dogmatic insistence on the allocational efficiency of the market through the private ownership of the means of production. It is a simple but all pervasive doctrine and one which combines the two main and different components within the Chicago School: the neo-Austrian subjectivists under Hayek, and the positivist monetarists under Friedman.

In spite of important differences within the Chicago School, all believe in the need to maintain the process of competition (it is not a perfect competition general equilibrium model, but rather an unending and changing tendency towards an equilibrium model - an automatically adjusting catalaxy in Hayek's phrase) against that which threatens it. What threatens this process of competition is a certain sort of state interference and the activities of monopolies, particularly trade unions (employer monopolies are not considered very important, and on the whole it is argued that state interference to break up these monopolies has been more harmful than beneficial). It should be emphasized that this is not a laissez-faire position: indeed both Hayek and Friedman advocate the need for a strong state which actively ensures the workings of competition, eg in the field of industrial relations. What is important is that the state acts within a proper set of principles designed to ensure that the rules of the game are universal and impersonal.

The Chicago model then, is essentially an exchange or circulationary model in which individual or household knowledge of prices and costs to achieve efficiency can only be acquired by the operation of market processes themselves. As it is an exchange model, social classes, of course, make no appearance. The

\footnotetext{
${ }^{2}$ The establishment of free-market think-tanks has been important. In Chile these included CESEC, and under Allende, the Instituto de Estudios Generales, and in 1980 a Centre for Policy Studies was established with Friedrick von Hayek as Honorary President.
}

emphasis is on individual liberty which, in turn, is defined in terms of the market place. The Chicago School consider the market to be non-coercive by definition, and liberty is defined as 'that condition of men in which coercion of some by others is reduced as much as possible in society'.

Democracy may help economic liberty, but it is not a necessary condition for it. It is, therefore, possible for economic liberty to exist within an authoritarian regime. ${ }^{3}$ Indeed, democracy, it is argued, can endanger liberty by giving to the state all sorts of powers which threaten the exercise of individual liberty, and must, therefore, be controlled and limited through severely restricting state activities and confining these to strengthening the market and the rule of law and weakening organisations such as political parties and trade unions. $^{4}$

As a model for Chile and other underdeveloped countries, this basic paradigm added a number of other emphases, the most important being the doctrine of comparative advantage and an assertion that Third World countries do best by integrating themselves into the international capitalist economy. 'Inwardlooking industrialisation' was considered a failure, for 'such industrialisation was highly inefficient and prone to be self-limiting, if not self-defeating, and what was required was access to larger, foreign markets' [Johnson 1971|. Coupled with this was the view of the multinational corporation as the development agency, and hence the demand for an open policy towards them. The new model also emphasized the need to develop a capital market ${ }^{6}$ In addition, they offered a monetarist explanation of inflation.?

\footnotetext{
${ }^{3}$ Hayek has argued that it is possible that "democracy can acquire totalitarian powers' and that 'an authoritarian government can act according to liberal principles'. There is now a host of right-wing authors emphasizing the dangers of democracy to the functioning of $z$ capitalist economy.

${ }^{4}$ Clearly, what the model does not want to recognise is that historically, as Macpherson has pointed out [Macpherson 1973], there has been a tendency that the pure market leads to political power being used not to offset, but to reinforce economic power. Hence, contrary to the Chicago position, the growth of political parties, trade unions, the welfare state, and much state intervention, had been experienced by millions of people as a way of checking economic power by political power, and not as an intrusion into their liberty.

${ }^{5}$ The ex-President of the Chilean Central Bank. A Bardon's commonly quoted phrase. "If comparative advantage determines that Chile should produce nothing but melons. then we will produce nothing but melons'. sums ups this attitude.

'This was given a particularly strong emphasis in Chile. In this field and others R. I. McKinnon has played an important advisory role: and the Chilean model could perhaps best be interpreted as a mixture of his ideas together with the Chicago School, plus some crudities from Chilean military national security doctrines.

'In the Chicago 'underdevelopment' model, any historical or structural explanations of underdevelopment are discarded and the emphasis placed on the market allocation of resources, and the necessity of removing obstacles to the efficient operation of international and national markets. In one Gordian stroke, the bulk of post-war development theorising is thus cut out of consideration.
} 


\section{The Chicago Boys and the Making of the Coup}

The Popular Unity experience provided the Chicago Boys with perhaps a unique opportunity to influence the course of events for the implementation of their model. But it should be made clear, of course, that neither they nor any other group caused the coup. They took advantage of the deep-seated crisis which emerged at every level of society during the Allende period. And the Allende crisis was in turn the outcome of a long process of political and economic difficulties associated with nearly all semi-industrialised countries undertaking an import substitution industrialisation strategy. The economic difficulties were exacerbated during the Allende Government; as a result by 1973 inflation reached very high levels (around 600 per cent) and foreign exchange reserves were exhausted.

In Chile this crisis took a particularly acute form under Allende, requiring a more dramatic response after the coup. It was this experience which perhaps explains the degree of 'relative autonomy' of the state apparatus after the coup, allowing a relatively small group of people to push through a series of drastic reforms which, in the short run, went against the immediate interests of so many sectors of Chilean capital.

How, then, did the Chicago Boys organise themselves during the Allende period so that they would be in a position to seize the initiative after the coup, and become the 'vanguard party' of a section of the Chilean bourgeoisie? A partial answer lies in the role they played in the making of the coup. In the feverish atmosphere of Allende's Chile, there was no shortage of groups plotting and planning Allende's downfall. There were two key problems: how to coordinate these groups into a mass opposition movement and how to push the armed forces into making a coup. No group per se was the pawn of another group: only after the coup was it clear who was using whom, and this only through a post hoc ergo propter hoc deduction. Nevertheless, an examination of those key groups organising for the coup reveals an important role for a group of Chicago Boys.

The initial opposition to Popular Unity (apart from the early CIA-inspired disruptive tactics like the murder of General Schneider) was organised through the main opposition political parties, the Christian Democrat Party and the National Party. But when the struggle passed beyond the confines of the Congress and the Senate, the political parties of the right played an increasingly subordinate role to the gremialismo movement (representing the corporate interests of employers and professionals, and later, women and youth and sectors of the labour movement). The role of right-wing political parties was to stall Popular
Unity legislation, support the mass movement of opposition, and legitimise the coup by declaring Allende and Popular Unity illegal. The non-democratic wing of the National Party willingly accepted this, and indeed, had been preparing for such moves by winning leadership positions within the gremios: but the democratic wing of the National Party and the Christian Democrats found that the effective leadership of opposition to Popular Unity had slipped out of their hands.

There was undoubtedly an element of spontaneity in the gremialismo movement, but it still needed coordination and finance. Responsibility for this was taken by a shadowy group of businessmen known as the Monday Club, so-called because its members met almost every Monday to coordinate activities. The key members of this group included several Chicago economics graduates; amongst them, Manuel Cruzat, who was later to emerge as the head of one of the two largest economic groups in Chile. In the words of one member of this group, 'We met roughly on a weekly basis from the middle of 1971 onwards to plan the media campaign, organise and coordinate actions, particularly of the gremios, and to distribute money, much of which came from abroad', (interview with $O$ Saenz, 16 June 1980). Members of this group also had contact with the terrorist neo-fascist organisation, Patria y Libertad, whose leader, Pablo Rodriguez, was to complain after the coup that promises made to him on economic matters had been broken.

Preparations for a coup began in the Navy. Their main go-between to members of the Monday Club was an ex-navy officer Roberto Kelly, who after the coup was to become head of the National Planning Office, ODEPLAN, and later Minister of the Economy. One of the worries of the navy officers was, of course, what to do about the economy after the coup. Kelly volunteered to arrange for a detailed plan to be drawn up. A group of Chicago-trained economists had been meeting periodically and informally to discuss the economic situation throughout the Allende period. But after March 1973, at the request of the navy officers and certain business interests, a group of Chicago Boys met to draw up an economic plan to be implemented after the fall of Allende.

Ten leading economists drew up this plan. They were A. Bardon, A. Sanfuentes, J. L. Zabala and Juan Villarzu, virtually the Departamento Técnico of the Christian Democrat Party, P. Baraona, and S. Undurraga of the National Party, and Sergio de Castro, Manuel Cruzat, Juan Braun and Emilio Sanfuentes, closely linked to entrepreneurial and gremial groups. ${ }^{8}$ The

\footnotetext{
${ }^{8}$ All but two were trained in Chicago. These two, J. Braun and $\mathrm{S}$. Undurraga, are considered by the Chicago Boys as Honorary Chicago Boys. as also are J. Cauas, ex-Minister of Finance, and J. Piñera., Minister of Mines.
} 
plan was systematically leaked to certain naval officers who, in turn, leaked it to certain airforce officers (the army seems to have had a minor role in those days). By the time of the coup a 280 -odd page plan had been written, and was in the hands of the Junta. Not surprisingly, virtually the day after the coup many of the authors of the plan entered the key Economic Ministries as 'advisers'.

The above account is not intended to support any conspiratorial theory of history (for it does not explain why one 'conspiracy' wins or loses), but rather to emphasize the importance of class organisational capacities and the role of particular networks in providing them, and to show that the Chicago Boys fed into a highly effective organisation linked directly to leading business interests. (It is indicative that, in moments of crisis, it is leading businessmen who become long and short-term political planners rather than traditional politicians.)

This brief history helps explain how the Chicago Boys came to dominate certain key sectors of the state after the coup. One of their notable characteristics is their attempt to combine theory and practice, and to take advantage of crises when they come to restructure the economy and society according to their philosophy (for these characteristics they have been rightly called 'the Marxists of the Right'). In Chile, some Chicagotrained economists became leading entrepreneurs, eg Manuel Cruzat and Rolf Lüders; others became leading members of the economic groups after a period in government, eg Pablo Baraona. All closely identify themselves with business interests. Many connect themselves to right-wing think-tanks. They have a strong sense of social cohesion ("we are the brightest and the best'), of dedication to their tasks, and of team-work (in the words of one of them, 'we have an unwritten pact among ourselves not to resign in protest or sympathy if one of us gets sacked, but to carry on to win our aims'). They thus act as a 'vanguard party', and are indeed highly effective 'organic intellectuals.'

\section{The Initial Phase : the Period of Transition, September 1973-April 1975}

The original economic plan was a product of independent economists, nearly all trained in Chicago. Nevertheless, the plan was also a politically 'negotiated' document. Leaders of the National Party and the Christian Democrat Party knew that members of their party were involved in designing a plan, and to that extent gave their blessing, but neither party gave its official consent to participate in designing the plan, or approved it afterwards. The plan was also 'negotiated' in another sense in that it was clearly a compromise between the 'soft' Christian Democrat Chicago Boys, and the other hard-liners. As such, and given the role of the Christian Democrat economists in the government after the coup, it was initially difficult for the Christian Democrat Party to oppose the general direction of economic change.

Politically, the initial situation was very confused. The original structure of government decision-making was that of a Junta with a genuine degree of decentralised decision-making to each member of the Junta. The early stages involved much political in-fighting, but over a period of time, General Pinochet did away with the dispersal of power within the Junta, centralising all decision-making within his own hands. This centralisation of power was supported both by the hard-line Chicago Boys, who realised that politically the implementation of their programme required the centralisation of power, and by the neo-fascist groups within the government, who wanted 'the leader' to implement their corporatist project, and the army whose weight within the armed forces made them resentful of equal treatment for all branches of the armed forces. At the same time, the Christian Democrat Party slowly moved into opposition, and the Christian Democrat economists either resigned from the government (eg J. Villarzu, A. Sanfuentes and J. L. Zabala) or resigned from the Christian Democrat Party and moved into the hardline Chicago position (eg A. Bardon and J. Cauas). Thus the Chicago plan needed General Pinochet: even a modified degree of internal democratic decisionmaking was incompatible with its implementation.

Even so, during the initial confused period, the Chicago Boys were able to make decisions of strategic importance for the implementation of the Chicago plan. Two early decisions, for example, were to implement a drastic programme of tariff reductions, in effect opening up the Chilean economy to the international economy, and to free prices. The decision that the structure of relative prices was more important than the absolute level of prices, and that the structure has to be that of the international economy, was of key political importance, and a typical Chicago tactic. As Emilio Sanfuentes was to argue afterwards, the freeing of prices was so inflationary that it led everyone later to be in favour of drastically reducing State expenditure and tariffs, two of the main objectives of the Chicago plan.

There were other decisions of key importance in this period. State enterprises, particularly the big loss makers, such as textiles, were privatised as quickly as possible. The first steps towards establishing a capital market were rushed through, and prepared the way for the spectacular growth of the economic groups. The exchange rate was drastically devalued and unified. A new foreign investment code was passed to attract foreign investment (this was later modified as having too many restrictions on foreign investment). Relations were normalised with the main international financial institutions such as the IMF, the World Bank and 
private foreign banks. Both the IMF and the World Bank rushed in teams shortly after the coup to give their blessing to the general direction proposed by the Chicago plan. But their role was not to impose on a reluctant Chilean Government, but to support the Chicago Boys against any opposition. All these measures moved Chile in the general direction designed in the economic plan.

However, the pace of change was regarded by the hard-line Chicago economists as insufficient for the complete restructuring of the Chilean economy. Chile was still too statist, too paternalistic in social welfare, and too protectionist. So even before the conjunctural crisis of 1975 , some of the Chicago group began to argue the need for 'shock treatment', ostensibly to end the inflationary spiral but also to restructure the economy, and to attack those advocating a 'gradualist' approach.

\section{The Second Phase: Shock and the Period of Restructuring, April 1975-December 1976}

The build-up to shock had, in fact, began in 1974 when El Mercurio published a series of articles attacking the delay in dismantling the state sector. In May 1974, this theme was taken up by Admiral Merino when he declared that public expenditure and not unemployment was the main enemy. In July 1974, A. Harberger put his weight behind this, arguing that you cannot have monetary stability without unemployment. Those favouring 'shock treatment' would probably have had difficulty in achieving the radical restructuring they wanted if the conjunctural crisis of 1975 had not forced the need for drastic decisions.

The conjunctural crisis began with the fall in the price of copper combined with the increase in the price of oil, and led the Minister of Finance to declare that Chile faced a $\$ 1,000 \mathrm{mn}$ loss for 1975 from these two factors, and that drastic action was required. This drastic action was put in stark terms: without unemployment, bankruptcies, and a drastic reduction in state expenditure, stabilisation would not work. Another theme was also emphasized: if drastic treatment was applied rapidly and logically an economic miracle would follow after an apparent two or three year economic period of hardships.

This line was supported by both Harberger and Friedman when they visited Chile in March 1975. Both emphasized that the policy of applying palliatives instead of amputating the diseased parts ran the danger that the final cost would be higher. Chile faced the choice of a short period of high temporary unemployment or a long period of high unemployment. Friedman reiterated the the immediate cause of inflation is always a consequence of a larger increase in the amount of money than production and this is clearly so in the
Chilean case. The first necessity therefore is to end inflation, and the only way Chile can do this is by drastically cutting the fiscal deficit, preferably by reducing public expenditure ... in Chile ... gradualism seems to me impossible' (El Mercurio, April 1975). At the same time, an IMF mission visited Chile, and agreed a stand-by credit with the government, which committed it to strongly deflationary policies.

After another piece of political infighting, the hardline Chicago Boys in effect secured an economic dictatorship. With the change of Cabinet in April 1975, Jorge Cauas was appointed Super-Minister in charge of most of the key ministries. He met on an almost daily basis with the newly appointed Minister of Economy, Sergio de Castro, the newly appointed President of the Banco Central, Pablo Baraona, and the head of ODEPLAN, Roberto Kelly. This four-man team directed the course of shock treatment. On the political side there had been a suspension of virtually all forms of "legislative" body and Pinochet was the sole political arbitrator, aided and abetted by the Chilean secret police, or 'DINA', whose influence grew by leaps and bounds. Paradoxically, therefore, the Chicago shock plan required the dramatic increase in the power of the DINA, although later the Chicago Boys were to turn against it.

The results of shock were dramatic. From the end of 1974 to the end of 1976 unemployment increased from 9.7 per cent to 18.7 per cent. GNP fell by 12.8 per cent in 1975 , perhaps the most dramatic fall in output seen outside of exceptional events like war or natural disasters; industrial production fell by approximately 27 per cent in one year! The Consumer Price Index fell from 376 in 1974 to 340.7 in 1975 , and to 174.3 in 1976.

The loss in the terms of trade from the fall in the copper price and the increase in the oil price has been calculated by Foxley [1979] to be equivalent to 5.6 per cent of GNP. Yet GNP fell by much more, ie the recession engineered by shock went far beyond anything required to maintain Chile in its original position. In other words, the purpose of shock treatment went much further than to confront the particular conjunctural crisis. Rather, the Chicago Boys used shock tactics to put through the particular restructuring which they thought necessary for their long-run objectives.

One can see this from a whole series of policies pursued throughout 'shock'. The average tariff was reduced from 52 per cent at the beginning of 1975 to 33 per cent at the end of 1976 , with the highest tariff rate being reduced from 120 per cent to 60 per cent. The process of privatisation continued, even of those enterprises which were not making a loss, and even though the state sold them in a period of recession and therefore at a very reduced price. Also the drive to establish a capital market continued, and various 


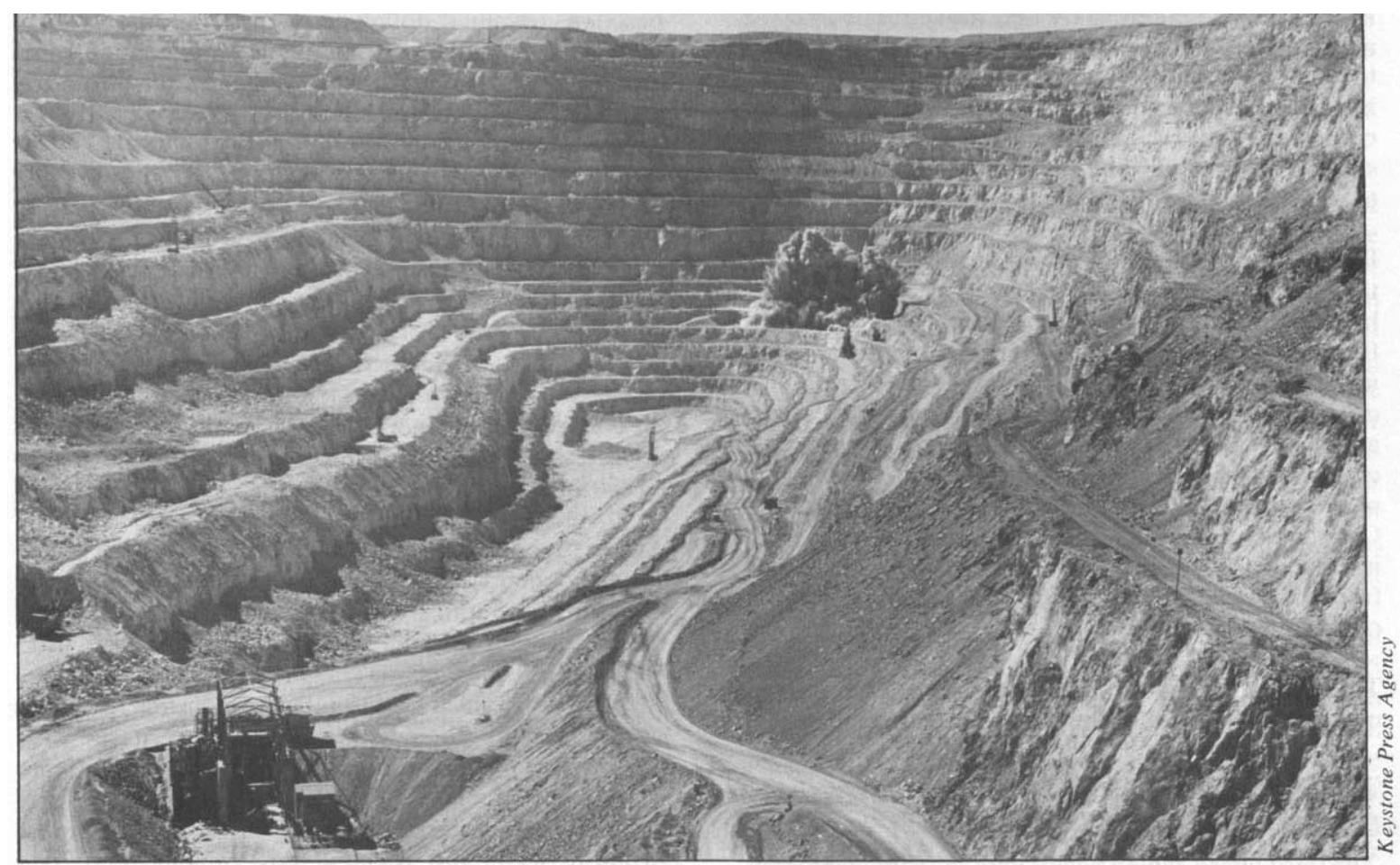

The Chuquicamata open-strip copper mine.

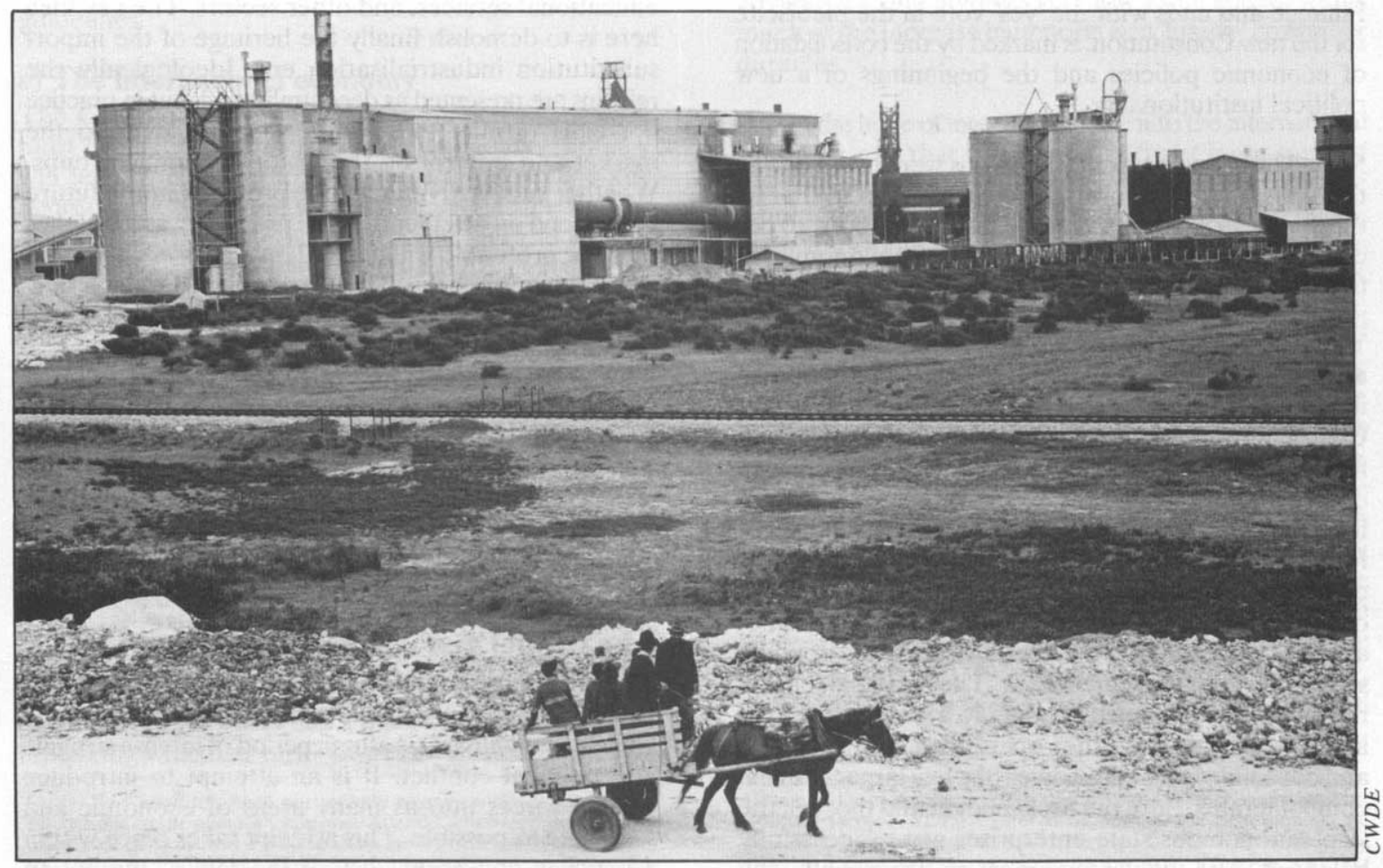

The new cement plant near Concepción, about 350 miles south of Santiago. 
measures were taken to try and move funds into the new financial institutions. The drastic devaluations, together with the dramatic collapse of internal demand, in effect reduced imports (no attempt was made to control the type of imports) and expanded exports to such an extent that Chile initially moved from a deficit to a surplus on its 1976 balance of trade.

By the time these policies eased, at the end of 1976 , the Chilean economy had been restructured. Exports became the more dynamic sector. Industry faced fierce competition from foreign manufacturers and, with the collapse of its internal market, was clearly in a difficult position. The state's economic and social activities had been drastically curtailed. The working class was weakened through repression and the creation of a massive 'industrial reserve army'. Finally, the Chilean economy was effectively integrated into the international capitalist economy: the Chilean withdrawal from the Andean Pact in 1976 was a formal recognition of this.

The key question remained-would the economic miracle follow, as the Chicago Boys had promised?

\section{The Third Phase: the Period of Consolidation, 1977-80}

The third phase, which begins with the replacement of Jorge Cauas by Sergio de Castro in the Ministry of Finance and ends with the 'yes' vote in the plebiscite for the new Constitution, is marked by the consolidation of economic policies and the beginnings of a new political institutionality.

Many key economic policy decisions were taken during this phase. Tariff reforms were speeded up so that by the end of 1978 Chile's average tariff was about 10 per cent, making Chile one of the most open economies in the world.

Virtually all restrictions on the contraction of debt abroad were removed which, given the situation of liquidity in the international monetary market, meant Chile had around $\$ 3 \mathrm{mn}$ a day entering into it. The foreign investment code was reformed towards an open policy of removing all restrictions on foreign investment in an effort to maximise the entry of foreign investment. The process of privatisation was continued, and where this met resistance from sectors of the armed forces and trade unions, privatisation of as many as possible of the ancillary services around a state enterprise was carried out. The financial market reforms were deepened, leading to a massive upsurge in stock market and other operations, and a growth and consolidation of the power of a few large financial conglomerates. Both the fiscal budget and those of the semi-autonomous state enterprises were successfully balanced. And, finally, and most controversially, the peso was revalued, followed by a period of crawling devaluation, until finally in 1979 the exchange rate was fixed at 39 pesos to the dollar in an effort to stabilise Chile's rate of inflation at the international rate.

Politically this period saw the open outbreak of major differences within the government. The 'new democracy' was meant to culminate in the plebiscite of 11 September 1980 , in which more than 60 per cent of the population voted 'yes' to the Constitution of Liberty. However, the Constitution did no more than ratify the concentration and personalisation of power in the hands of one person, General Pinochet, in that the full operation of the Constitution was postponed for a transitional period of eight years.

Aware of the danger and fragility of having a political system depend so much on one man, the Chicago Boys are attempting an institutionalisation of their model through sectoral 'modernisations'. So far this has involved such major transformations as the new 'Plan Laboral,' which has instituted an industrial relations system in accordance with their market criteria; the reform of the social security system, which in effect will privatise the massive pensions funds putting them into the capital market; the reform of public administration, local and regional government; and the extension of the process of privatisation to health and educational services, and other sectors. The key idea here is to demolish finally the heritage of the import substitution industrialisation era. Ideologically the reforms are presented as decentralisation, but in practice it means turning these state activities over to the market and control by the major economic groups. Whether such activities will be provided in the future will depend on whether they are profitable, and whether they are profitable will depend on a person's ability to pay. Education, health, housing and welfare will thus no longer be a right but a privilege for the few.

Thus, if one looks at the speed and extent of reforms in Chile, there can be little doubt that Chile is undergoing a 'successful' counter-revolution both economically and institutionally. It has, in effect, become an example of the authoritarian version of the Chicago model. We now turn to see what are the main contradictions of this imposed model.

\section{The Model and its Contradictions}

The model is essentially a very simple one, which perhaps helps explain its attraction for sections of the Chilean capitalist class after a period of intense struggle and political conflict. It is an attempt to introduce market forces into as many areas of economic and social life as possible. This attempt takes place within a logically consistent view of the role of the nation 
state, and in turn its position within an international economy.

It is important to emphasise the difficulties in trying to establish what has actually happened in Chile. Those in favour of the model tend only to emphasise the recent high growth rates, the decline in inflation, the growth of non-traditional exports, the large foreign exchange reserves, the reduction of state expenditures and a balanced fiscal budget - all within the framework of political stability and law and order; whereas those against the model point to the high rates of unemployment, the worsening distribution of wealth, income and power, the rise of the foreign debt, the low level of accumulation, the suppression of democracy and the use of terror, force and censorship against opposition-in short, an economic dictatorship supported by bayonets.

On many issues, eg real wages, there are two sets of statistics: those of the government and those of the opposition. There are genuine difficulties in compiling aggregate indices within an economy undergoing profound and rapid structural changes, together with very large and irregular price movements, but these difficulties are compounded by a tendency to manipulate the figures, particularly by those favouring the model. This article uses these official statistics, supplemented on certain issues by alternative statistics. The statistics should, therefore, be treated as no more than tentative guidelines.

\section{a) The international economy}

The Chicago position is that the market framework must be that of the international economy; if not, it will lead to pressure for state interference. The key decision in Chile then, was to integrate Chile as fully as possible to the international economy, and let that market 'impersonally' impose a restructuring on Chilean economy and society.

Within this move to integration, the key was that of drastically reducing tariffs (at the time few Chilean capitalists, apart from Vial and Cruzat, believed this was possible. ${ }^{9}$ In his first speech after the coup, the then Minister of Finance, Admiral Gotuzzo, announced a programme of tariff reductions. Consequently, first Jorge Cauas and then Sergio de Castro speeded up this programme, so that within the short space of six years, Chile moved from being a highly protected economy to one of the most open economies in the world. In December 1973 Chile had 5,125 specific tariff duties of which 42 ( 0.8 per cent) were less than 10 per cent and 1808 ( 37 per cent) more than a 100 per cent, with an average median tariff of about 94 per cent. The

\footnotetext{
${ }^{9}$ Sergio de Castro has been particularly strong on this point. In the discussions on the plan for Chile post-Allende, when tariff levels were discussed, he proposed a zero tariff to ensure that the average tariff level proposed would be as low as possible. (Interviews with various members of the original team.)
}

trajectory of the median tariff was as follows: June $1974=67$ per cent; August $1975=44$ per cent; June $1976=33$ per cent; December $1976=27$ per cent; December $1977=15.7$ per cent; December $1978=11.9$ per cent and December $1979=10.2$ per cent.

This quickly revolutionised the extent and structure of Chilean foreign trade. Total value of foreign trade increased from $\$ 2.8 \mathrm{bn}$ in 1973 to $\$ 10.53 \mathrm{bn}$ in 1980 ; exports increased from $\$ 1.31 \mathrm{bn}$ in 1973 to $\$ 4.86 \mathrm{bn}$ in 1980 and imports from $\$ 1.45 \mathrm{bn}$ to $\$ 5.69 \mathrm{bn}$. A rapid increase in 'non-traditional' exports can be seen, moving Chile away from its traditionally excessive dependence on copper exports. In constant 1975 US\$ non copper exports increased from \$344mn in 1973 to $\$ 906 \mathrm{mn}$ in 1978, of which the most important were paper and wood products, fishmeal and frozen shell-fish, fresh fruit and some metals essentially associated with copper, eg molybdenum. By 1980 therefore, copper represented only 43 per cent of exports compared to about 73 per cent in 1973. On the import side one can see a dramatic decline in the import of foodstuffs from 35 per cent in 1973 to 12 per cent in 1980; there was also an increase in the import of consumer durables (from 9.6 per cent to 17.2 per cent) and of intermediate goods (this includes fuels and lubricants) from 38 per cent to 49 per cent, with capital goods increasing slightly from 16.8 per cent to 20 per cent. The growth in exports clearly reflects natural comparative advantages, and involves very low value added, whilst much of the increase in imports is in 'luxury' consumer durables.

Part of the hope of integrating Chile into the international economy was that Chile would attract large sums of direct foreign private investment, and that the multinational corporations would act as one of the main 'development agents'. This has not happened. In spite of one of the most pro foreign investment codes in the world, Chile has failed to attract much direct, foreign investment. Since 5 August 1974 (the date of the original D.L. 600 , later modified by Sergio de Castro into an even more favourable code for foreign investors) some 453 investment projects have been approved worth about $\$ 429 \mathrm{mn}$, and out of this only some $\$ 751 \mathrm{mn}$ has actually entered the country. Of the authorised projects $\$ 3,740.2 \mathrm{mn}$ is in mining, of which only \$298.3mn has entered. The overwhelming majority of investments approved therefore, is in mining, but as this is a long gestation in mining projects, much of the approved investment may still take place. In some cases it seems that the offer of large investments, by, eg Rockefeller, was in part motivated by political reasons. ${ }^{10}$

${ }^{10}$ The support given by ADELA (the Atlantic Community Development Group of Latin America) seems to have been strongly motivated by political factors. ADELA offered support at a critical moment of Chile's international isolation to strengthen the hands of the Chicago Boys and their supporters. (Information from interview with M. Valdes, 17 June 1980.) 
The main way that Chile has integrated herself into the international capitalist market has been through a mechanism the Chicago Boys could not have foreseen in 1973, namely, the contracting of private foreign debt. With the massive growth in international liquidity, Chile has contracted a large level of loans on the private capital markets. As of December 1978 Chile became top of the debt league, having the highest per capita debt in the world at $\$ 644$ per inhabitant and, in absolute terms, eighth highest in the world. Since 1977 when foreign finance capital began to pour into Chile, $\$ 6,460 \mathrm{mn}$ has entered, of which $\$ 4,338 \mathrm{mn}$ (75 per cent) is private debt, almost entirely foreign banks lending to Chilean banks. And even out of the traditional foreign debt (ie the public sector's debt together with the private sector's debt guaranteed by the government) nearly 50 per cent $(\$ 2,367 \mathrm{mn})$ of the $\$ 4,893 \mathrm{mn}$ in 1979 came from private banks and financial institutions.

In terms of 1976 dollars, the traditional debt fell from $\$ 3,918 \mathrm{mn}$ in 1973 to $\$ 2,541 \mathrm{mn}$ in 1979 , a fall of 35.1 per cent, whereas the private sector debt increased from $\$ 889 \mathrm{mn}$ in 1973 to $\$ 1,701 \mathrm{mn}$ in 1979 , an increase of 91.3 per cent in real terms.

In 1978 Chile's debt service ratio was about 45.3 per cent, placing Chile third in the world league (after Brazil and Mexico) and over the last two years it has risen even higher. Clearly, a potential contradiction in the model must lie here. The Chicago Boys regard the debt as a sign of confidence in the model and see no need to restrain it; as long as money can be borrowed and repaid why worry? But as argued later, much of the debt has gone to finance consumption and buying up existing assets, and only a relatively small part of it to finance new productive investment. The consequences of this are now beginning to be felt. These problems have been worsened by the increase in interest rates in the USA which has increased Chile's service charges on its debt. Foreign bankers are beginning to become more wary, particularly following the multi-million dollar crash of Chile's sugar firm, CRAV. The dance of the millions could still come crashing down.

The massive inflow of private foreign loans is also partly responsible for Chile's return to a form of the Gold Standard. After a period of massive devaluations, a short revaluation of the peso in 1976 , followed by a period of crawling devaluations, the exchange rate was finally fixed in 1979 at 39 pesos to the dollar, and has since remained at that level. This policy, hardly orthodox Chicago, which believes in floating exchange rates, is designed to stabilise Chile's integration into the international economy. A fixed exchange rate together with a balanced budget is meant to ensure that Chile's rate of inflation is pegged to the international one. In addition, it is another way of subsidising the large economic groups. As the top five economic groups in Chile have contracted the overwhelming bulk of the private foreign debt, the fixed exchange rate is a way of subsidising their debt.

Thus with a fixed exchange rate, balanced budget, 'free' interest rate, and large foreign capital inflows and hence large foreign exchange reserves, the Chilean economy is left to adjust itself automatically to the international economy. Levels of production in Chile are to be determined by the international economy and not by national policies. Such is the logic of the Chicago School.

\section{b) The state}

The switch from traditional to private sector debt is but one indication of the new role of the state in the Chilean model. This role has been defined as 'subsidiarity', ie the state only undertakes those activities which the private sector cannot do (in practice, because of military ideology, exceptions are made on grounds of 'national security'-more often than the Chicago Boys would like). This was summed up shortly after the coup when Admiral Merino declared that 'there is no worse businessman than the state'.

In line with this there has been a rapid process of privatisation, so that out of the 464 firms under state control on 11 September 1973, some 394 had been sold by June 1977 (at a price of some $\$ 434.3 \mathrm{mn}$, a very undervalued sum), and the remainder, apart from some very minor ones, sold by June 1980 . Although an initial attempt, pushed by the Christian Democrat Chicago group, was made to try and disperse the sale of state firms, so as to avoid the problem of concentration, this was soon abandoned, and market criteria were the sole criteria applied, and the sales accentuated the trend towards concentration.

Within the state sector itself ODEPLAN, the State Planning Office, gained a degree of control which would be the envy of many a Planning Office elsewhere, and not least of Allende's planners. Together with the Minister of Economy and the Minister of Finance the existing state sector was re-organised and ran without a deficit. Of the nine wholly state owned firms (excluding copper) in 1979 with a total expenditure of $\$ 2,622.8 \mathrm{mn}$, income was $\$ 2,643.3 \mathrm{mn}$ giving a surplus of $\$ 20.5 \mathrm{mn}$. And for the first time in many years the fiscal budget had a surplus of 7.5 per cent of total expenditure in 1979 , which was a great contrast to the 55.1 per cent deficit in total expenditure in 1973. Paradoxically, the state sector has never been so thoroughly planned as under the Chicago Boys (ODEPLAN vets all expenditure plans).

Within state expenditure there has been an increase in expenditure on the armed forces and the police (in equipment, armaments, number of men, and material provisions, the armed forces are an 'island of welfare socialism' completely sheltered from the market). 
State/civil society relations have also been altered. Pressure groups, including the formal ones of the dominant classes, are not meant to act as pressure groups on the state, or be consulted on policies affecting them. State decisions are meant to be 'technical', free from civil society pressures. Indeed the leadership of the main pressure groups has become a pressure group of the state rather than on the state. Their role has been to persuade their constituent members of the correctness of the government's line, and defuse potential protests and action against the Chicago line. This socalled 'neutral technification' of the state has been extremely effective in disarming non-political party opposition: protest is particularistic and therefore non legitimate. At the same time, of course, it has aided and abetted the spectacular process of concentration in Chile.

\section{c) Monetary policy and inflation}

\section{i) Money}

Money is considered crucial in the Chicago model. The Chicago School places particular emphasis on the importance of price, and the role of prices in determining allocation (prices, of course, are meant to. be determined by the 'natural' processes of competition). Hence the importance of money as the unit in which prices are expressed. If this unit is unstable then the processes of competition become distorted. Inflation, therefore, for the Chicago School is public enemy number one. In addition, as Friedman has frequently emphasized, inflation is a politicising process, one that can lead to the breakdown of society and revolutionary outbreaks (there can be little doubt that the highly politicised nature of Chilean society is partly related to its long history of high inflation rates since the 1880s). The choice of this target also allows them to attack two institutions they are opposed to-the state and trade unions; as well as what they regard as the Achilles Heel in Keynesian theory.

One of the first acts of the Junta after the coup was the freeing of prices. For the economic team, price controls signalled repressed inflation. In their view, logically according to the Chicago model, if there is something worse than open inflation, it is repressed inflation. In 1973 about 4,000 products were subject to price controls; by 1978 this was down to eight. The freeing of prices, combined with massive devaluations, meant a rapid increase in the rate of inflation, thus preparing the ground for the introduction of 'shock treatment'.

Mainly for political reasons the emphasis in Chile, unlike in Britain, has been less on the money supply per se and more on fiscal expenditure. There has undoubtedly been a correlation between the decrease in the rate of inflation and the decrease in the rate of growth of the money supply. Such a correlation, however, says nothing about causal connections nor indeed about the social costs involved. The model then has been successful at reducing the rate of inflation from 508 per cent in 1973 to 31.2 per cent in 1980 , but much more slowly than predicted, (this is contrary to the Chicago experts' predictions).

Interestingly the shock period did not produce the desired results as regards inflation. And within the anti-inflationary policies the attempt to control money supply proved difficult; the brunt of the anti-inflationary policy was a drastic reduction of demand by reducing wages and government expenditure. Fiscal spending as a percentage of GDP expenditure thus fell drastically during shock (at the end of 1975 it was 46 per cent less than its 1973 per cent level), and the cut in fiscal spending combined with the tax reforms of 1974 and 1975, which essentially replaced the sales tax with a value-added tax, doubling government revenues as a percentage of GDP over the period, reduced the fiscal deficit from 23.5 per cent of GDP in 1973 to only 1.2 per cent in 1978. These shifts involved a substantial change in the distributional role of the state. The abolition of the capital gains tax and other reforms benefited the capitalist class; and the shift in fiscal expenditure from education, health, housing and construction into defence and unemployment benefits penalised the poor.

The growth of money supply shows an erratic pattern, revealing the difficulties in trying to control the money supply directly. And indeed the Chilean economic team have never publicly set themselves money supply targets. Nevertheless, until 1977 controls on domestic and foreign credits were severe, with reserve requirements of up to 50 per cent, for example. But after 1977 when controls on foreign credits began to be dismantled, monetary policy became a secondary instrument in government control policies.

However, there has been a revolution on the monetary side in Chile, with a completely new legislative position for banks and financial institutions. The development of a capital market was, from the beginning, one of the key objectives of the Chicago Boys, and its development shows how the economic team used the reforms they pushed through to assist themselves and those of their key backers. This, however, they would not regard as the old-fashioned style of 'corruption' but rather the blurring of the line between public and private interests, a line Chicago philosophy does not recognise. "Thus when the banks remained 'nationalised', legislation was passed freeing the rate of interest for finance companies which helped the spectacular growth of the Vial economic empire. When the banks were sold no attempt was made to prevent the concentration of

\footnotetext{
"A 'Who's Who' of the Chilean economic team and their subsequent positions after leaving the government shows a high concentration of them in top positions in the Cruzat and Vial empires.
} 
the banks in few hands (contrary to the official legislation). The rate of interest was freed and policies undertaken to unify the capital markets by ending the differential policies between the various financial and banking sectors (in June 1975 government policies, in effect, ensured the transfer of funds from the public sector institution, SINAP, to the private sectors).

The freeing of interest rates led to a rapid increase in the real rate of interest as can be seen from the following table:

table 1

\begin{tabular}{ccc}
\multicolumn{2}{c}{$\begin{array}{c}\text { Short-term average real interest rates in Chile } \\
\text { year }\end{array}$} & $\begin{array}{c}\text { lending rate } \\
\%\end{array}$ \\
& borrowing rate \\
1975 & 15.9 & $\%$ \\
1976 & 64.2 & 11.9 \\
1977 & 57.2 & 41.9 \\
1978 & 42.6 & 41.3 \\
1979 & 22.0 & 36.2 \\
& & 20.9
\end{tabular}

Source: A. Ferrer, 'El Monetarismo en Argentina y Chile', Comercio Exterior, no 1, January 1981.

The spread between the lending and borrowing rate meant those in charge of the financial markets could make high profits. And, equally important, especially after 1977, was the gap between foreign and domestic interest rates, making it very profitable for those few Chilean institutions with access to foreign credit.

The development of the financial market combined with the rapid privatisation of the public sector has led to an extreme process of concentration of capital in Chile. The existence of powerful economic groups dominating the economy is not something new in Chile: but never before have so few groups dominated so much. In the most comprehensive study of the problem Dahse [1979] has shown that five economic groups own 53 per cent of assets of the top 250 private firms in Chile (including foreign), in effect controlling the economy outside the state sector (which, as argued here, is to a great extent run by protégés sympathetic to the leading groups). The recent reforms of the pension funds have further increased this process of concentration, with the Cruzat and Vial groups capturing 73 per cent of the funds.

Each economic group is centred around control of a bank and/or financial institution which acts as the nerve-centre and headquarters of all the group's other activities. Chile is seeing, in effect, the transition to bank control of its economy: it is essentially the banks which determine the allocation of resources. ii) Materials of production

The model as applied in Chile has a very simple view of materials of production: national materials are whatever is naturally abundant; land, sea and minerals; the rest are to be imported. Transfer of technology is thus not a problem: exports, in effect, are (to use Marxist terminology) the Department I of the economy, supplying foreign exchange to import the means of production. This is, of course, a return to the simplest version of Ricardian comparative advantage, and has important consequences for labour skills and political democracy. Skilled labour is hardly needed, nor is an elaborate educational system to train it. And there is, of course, a contradiction between political democracy, and all the pressures for change which accompany democracy, and a low-wage economy with mass unemployment.

iii) Labour power

It took the Chicago team some six years to finally gain control of the Ministry of Labour and push through a new body of trade union legislation in keeping with the overall philosophy of their model, the Plan Laboral [see Haworth and Roddick 1981]. The earlier period of simple repression (which the Chicago team did not regard as unnecessary) has now given way to 'free, non political trade unions', although repression has certainly not ended. The new legislation, which is a sophisticated overturning of all the old labour legislation, is designed to atomise and weaken the trade unions by subjecting them to the so-called strict laws of the market, and, in effect, to individualise and commoditise labour. The Chicago Boys are fond of arguing that labour is a commodity like any other commodity, subject to the same universal, impersonal economic laws. Thus any attempt at political, class solidarity or even interfactory supportive actions are prohibited. Strikes are legal, but the legislation is designed to ensure that the workers stand little chance of success. Collective contracts do not exist in legal terms. Collective bargaining is reduced to a summing of individual negotiations between worker and employer.

The efficient operation of labour markets as defined by Chicago does require unemployment. The actual rate of unemployment is subject to much controversy, but even the minimum figures show that it has ranged from about 20 per cent in 1976 to 13 per cent in 1980 (16-17 per cent with PEM) ie contrary to Friedman's claim that high unemployment would be a temporary feature of the model, it looks as if the 'natural rate of unemployment', to use a Friedman phrase, will permanently be above 10 per cent. Few sections of the work force can bargain for higher wages in such a situation, as the collective agreements in 1980 show.

Unemployment also plays an important political role in dividing and weakening the trade union movement which still remains divided, weak and demoralised. 
Indeed, the architect of the Plan Laboral, Jose Piñera, believes the Plan will depoliticise the Chilean labour movement much more effectively than repression, or a government-controlled union movement. This Plan, together with a repressive competitive, individualised, consumerist society /see Filgueira's article in this Bulletin |, is designed to ensure that collective action is difficult.

Unemployment, of course, is not only a waste of resources but a human tragedy. But even many of those with work have seen a fall in their standard of living. Again, what has happened to income distribution is subject to fierce controversy, but the overall conclusion must be that there has been a general worsening of income distribution.

So, even apart from the very brutal repression and suppression of democracy at all levels, Chile faces a potential social time bomb, and it is this which is the main contradiction of the Chicago model. Politically the opposition has been inept at reorganising itself to face the challenge of the Pinochet regime (though there are understandable reasons for this), but the feeling of frustration and bitterness goes very deep in Chile. And the Chicago model is remarkably insensitive, applied as it is with a dogmatic arrogance bordering on the pathological.

iv) Conditions of work

The productive process has been characterised by a return to rigid, hierarchical controls within the workplace. Early flirtations with an Estatuto Social de Empresa were soon abandoned, and instead workers have no rights whatsoever over work processes or conditions, which are by law excluded from collective bargaining. Evidence is scanty, but it seems that health and safety conditions have declined and payment of social security benefits decreased. Given the nature of the commodities the model is designed to produce, there has been a process of deskilling of the labour force (a fact reflected in the restructuring of education and health), in which a low wage, unskilled work force becomes a part of Chile's comparative advantage. Such a process is and will be hard to reconcile with political democracy, particularly when the work force has been used to something different.

\section{v) Structure of production}

There has been an important change in the structure of commodities produced away from industry, particularly those industries producing for the internal market, towards agricultural, agriculturally based (although they technically appear as manufacturing) and mining exports. A whole range of products: textiles, furniture, printing, leather, non electrical machinery, were significantly below their 1968 level in 1978. All these products are basically catering for the domestic market. Other industrial products have increased their production, such as paper, drinks, petroleum, basic metals, etc, basically those (apart from petroleum) destined for export.

The distribution of GDP by sectors reveals the shift away from industry, as Table 2 indicates.

table 2

Chile-distribution of GDP by sectors 1973-77

(\% in 1965 constant prices)

$\begin{array}{lrr}\text { sectors } & 1973 & 1977 \\ \begin{array}{l}\text { Agriculture } \\ \quad \text { (including forestry }\end{array} & & \\ \quad \text { and fishing) } & 6.9 & 10.1 \\ \text { Mining } & 6.6 & 11.8 \\ \text { Manufacturing } & 26.1 & 20.6 \\ \text { Construction } & 3.6 & 2.6 \\ \text { Commerce } & 20.7 & 20.4 \\ \text { Other } & \underline{36.0} & 34.4 \\ \text { total } & \underline{100.0} & \underline{100.0}\end{array}$

Until 1980, in spite of a semi-destroyed internal market, there has been little problem of realisation: the markets are there for Chilean products. Income elasticity of demand for Chilean exports does seem to be greater than one, and particularly if the price of copper remains high (a big if), the terms of trade may be favourable to Chile. It does not look as if the model will collapse because international demand for Chilean exports will collapse, although the new order does mean that the Chilean economy is highly sensitive to, and dependent on, the international economy, the consequences of which have become clearer in 1981 .

\section{vi) Investment}

However, a major contradiction in the Chilean model is the low level of investment. There has been a significant growth in GNP since 1977, and this has led the Chicago Boys to predict a long run growth of 10 per cent per annum putting Chile firmly in the "economic miracle' class. This view has been supported by Professor Harberger, who recently stated in Chile that in ten years Chileans will enjoy a standard of living similar to that of Spain, with a domestic product at the moment about double Chile's, while in twenty years Chileans will possibly be enjoying the same standard of living as Holland'- provided, of course, that there is a constant application of the same policies.

The economic miracle' recedes somewhat if a closer look is taken at the GNP figures. In fact, Chilean per capita GNP has only risen from $\$ 1,841$ in 1971 to $\$ 1,920$ in 1979 . that is, and increase of $\$ 79$ over eight years or $\$ 10$ per year, which is hardly an economic miracle! 
The predicted 10 per cent per annum growth figure seems even less likely if one looks at the rate of investment. This has been well below the historical rate for Chile, and is one of the lowest in Latin America. ${ }^{12}$ So far the model has not led to a process of accumulation (although ODEPLAN predicts that investment will be 15 per cent of GNP in 1980 and are estimating that it will rise to 22 per cent by 1985). 1980 saw a decline in the growth of GNP to 6.5 per cent from 8.5 per cent in 1979, and the predicted growth rate for 1981 is down to 3 per cent to 4 per cent.

Now it may be true that many of the products Chile is exporting are low value added, technologically simple and with a high output capital ratio, and that Chile can grow fast with a low investment ratio. But for how long? It could also be argued that the fast growth rates after 1977 are a consequence of taking up some of the massive excess capacity engineered by the 1975-76 shock, a position supported by the fall in growth rates in 1980 and 1981 . The model, in fact, faces a dilemma: if the private sector does not reinvest within Chile and if foreign private capital does not invest, then the model faces a crisis of accumulation, unless the state undertakes a massive programme of investments which is precisely what the model is meant to avoid. Already the utilisation of installed capacity in the manufacturing sector is close to its limit (according to a SOFOFA survey installed capacity utilisation increased from 75.5 per cent in August 1979 to 81.5 per cent in August 1980). So will the private sector invest and if not will the state do it?

Until 1980 the Chicago Boys triumphantly proclaimed that their policies had produced an 'economic miracle', a miracle which they extrapolated into 10 per cent growth rate for the next decade and more. But in 1981 the problematic aspects of their policies became clearer.

Export earnings in 1981 are dropping fast. The price of copper has fallen from the very high $\$ 1.48$ per $\mathrm{lb}$ in February 1980 to 75 cents a lb in mid-1981. Chile's fastest growing non-traditional export, forestry products. which increased from 3.1 per cent of exports in 1973 to 12.1 per cent in 1980 , are falling by about 20 per cent. The fixed exchange rate is beginning to discourage small exporters, especially those who have to borrow locally. The increase in interest rates in the USA has dramatically increased service charges on Chile's debt and made the continuing flow of private bank loans into Chile problematic. The increase in real wages in 1979 and 1980 increased the demand for imported foodstuffs (the switch to exports in agriculture left the agrarian sector producing for the domestic market

${ }^{2}$ Faced with this problem ODEPLAN simply revised its statistics in 1981. Thus whereas ODEPLAN had previously shown investment as a percent age of GDP as 8.8 per cent in 1977 this has now become 13.3 per cent and the 10.3 per cent in 1978 has become 14.7 per cent and the 15.0 per cent in 1980 has become 17.9 per cent. very depressed), whilst the demand for consumer durables continues unabated. Thus with imports increasing and exports declining, the deficit on the commercial balance of payments could run to over $\$ 3,000 \mathrm{mn}$; with high debt service, the current account deficit will be much higher, reaching at least $\$ 9,000$ $\mathrm{mn}$. The authorities' response has been to allow interest rates to shoot up, pushing the economy into a recession with more bankruptcies, higher unemployment and lower wages, less government social expenditure, and further concentration. It also means an increase in repression: the government's sole response to social protest.

The key question remains, for how long are foreign bankers willing to finance the Pinochet regime in Chile? The answer to this depends not only on economic but also on political factors.

\section{Conclusion}

Milton Friedman himself has argued that there is 'an intimate connection between economics and politics . . only certain combinations of political and economic arrangements are possible' [Friedman 1962]. I have argued that there is nothing accidental about the combination of a repressive dictatorship and the Chicago economic model: indeed, the economic model could hardly be implemented without a dictatorship. Moreover. the Chicago Boys organised themselves politically to assist the process towards an extreme centralisation of power in Chile. This centralisation of political power has been accompanied by a concentration of economic power; in practice Chile is perhaps little more than a spectacular example of private greed masquerading as a model of economic development. In developed capitalist economies the Chicago model is likely to fail as people begin to fight back against its consequences. Unfortunately, in underdeveloped capitalist countries, where democratic procedures and institutions are virtually non-existent, or extremely fragile, resistance is met by repression. In these countries the Chicago model will necessarily be accompanied by dictatorship. repression and misery for the mass of the population. Such is the New Leviathan.

\section{References}

Dahse. F., 1979, in Aconcagua (ed) La Concentraciön de la Riqueza en Chile Santiago

Foxley, A., 1979, 'Inflación con recesion: las experiencias de Brasil y Chile', Working Papers no 46, Wilson Center, Washington

Friedman, M., 1962, Capitalism and Freedom, Chicago

Haworth N. and J. F. Roddick, 1981, 'Labour and monetarism in Chile', Bulletin of Latin American Research, vol 1 no 1 , September

Johnson, H. (ed), 1971, Trade Strategy for Rich and Poor Nations, George Allen and Unwin

Macpherson, C. B., 1973, 'Elegant tombstones: a note on Friedman's freedom'. in Democratic Theory, Oxford University Press 